\title{
DEVELOPMENT AND VALIDATION OF SPECTROPHOTOMETRIC METHODS FOR THE QUANTIFICATION OF EFAVIRENZ IN TABLETS
}

\author{
Sunitha PG* \\ Department of Pharmaceutical Chemistry, College of Pharmacy, Madras Medical College, Chennai-600 003, TamilNadu, India \\ *Author's Phone: 09840736172, E-mail id: sunitha.srm@gmail.com
}

Received 27 Sep 2012; Review Completed 27 Oct 2012; Accepted 06 Nov 2012, Available online 15 Nov 2012

\begin{abstract}
Two simple and precise spectrophotometric methods ( A and B ) were developed for the estimation of efavirenz ( EFZ ) in bulk drug as well as in pharmaceutical dosage form( tablets). Methods A is based on the formation of pink coloured chromogen by the diazotization and coupling reaction of EFZ with $\beta$-Naphthol. The $\lambda_{\max }$ of the pink coloured chromogen was found to be $494 \mathrm{~nm}$. Method B is First derivative spectroscopy method. The first derivative spectrum is a plot of the rate of change of absorbance with wavelength against wavelength ( $\mathrm{dA} / \mathrm{d} \lambda$ versus $\lambda)$. It is characterized by a maximum, minimum and a cross- over point at the $\lambda_{\max }$ of the absorption band. Beer's law was obeyed in the concentration range of $10-60 \mu \mathrm{g} / \mathrm{ml}$ and $4-24 \mu \mathrm{g} / \mathrm{ml}$ for methods A and B respectively. The proposed methods were statistically validated and found to be useful for the routine determination of EFZ in tablets.

Key words: Efavirenz, $\beta$ - Naphthol, First derivative spectroscopy, Tablets, Validation
\end{abstract}

\section{INTRODUCTION}

Efavirenz is an antiviral medication that prevents human immuno deficiency virus (HIV) cells from multiplying in our body. Chemically it is (+)6-chloro-4cyclopropylethynyl-1,4-dihydro-4(trifluoromethyl)2H-3,1 benzoxazin- 2- one ${ }^{1}$. Literature review revealed very few analytical methods including RP-HPLC, HPTLC and UVspectrophotometry for determination of EFZ in plasma, bulk drug and pharmaceutical formulations ${ }^{2-8}$. In the present work, two simple and sensitive spectrophotometric methods ( $\mathrm{A}$ and $\mathrm{B}$ ) have been developed for the estimation of EFZ in bulk drug and pharmaceutical dosage form. In Method A, EFZ is first diazotized with an aqueous solution of nitrous acid followed by coupling with $\beta$-Naphthol to form an azo derivative ${ }^{9,10}$ which absorbs intensely at $494 \mathrm{~nm}$. Method B is First derivative spectroscopic method. Spectrophotometric parameters are established for standardization of the methods including statistical analysis of data.

\section{EXPERIMENTAL}

Instrument: All spectral and absorbance measurements were made on Shimadzu UV-Vis Spectrophotometer1650 .

Standard solution of EFZ: A $1 \mathrm{mg} / \mathrm{ml}$ stock solution of EFZ was prepared by dissolving $100 \mathrm{mg}$ of drug in $100 \mathrm{ml}$ of ethanol.

\section{Sample preparation:}

Twenty tablets were weighed. A quantity equivalent to $100 \mathrm{mg}$ of EFZ was weighed accurately, transferred to a beaker, dissolved in ethanol, filtered through Whatmann filter paper No.1 into a $100 \mathrm{ml}$ volumetric flask and made up to volume with ethanol to get a concentration of $1 \mathrm{mg} / \mathrm{ml}$.

\section{ASSAY:}

\section{Method A:}

Aliquots of EFZ ranging from $0.25-1.5 \mathrm{ml}(1.0 \mathrm{ml}=$ $1000 \mu \mathrm{g}$ ) were pipette out into a series of $25 \mathrm{ml}$ volumetric flasks. To each flask, $1 \mathrm{ml}$ of sodium nitrite $(0.1 \mathrm{M}), 2 \mathrm{ml}$ of hydrochloric acid $(2 \mathrm{M})$ and $2 \mathrm{ml}$ of $\beta$-Naphthol $(0.5 \% \mathrm{w} / \mathrm{v})$ were added, mixed thoroughly and made upto volume with distilled water. The $\lambda_{\max }$ of the pink coloured chromogen was found to be $494 \mathrm{~nm}$ as shown in Fig. 1 . The absorbance of the pink coloured chromogen was measured at $494 \mathrm{~nm}$ against the reagent blank. The pink chromogen was stable for more than 3 hours. The analytical curve was constructed by plotting concentration versus absorbance.

\section{Method B:}

The stock solution was diluted suitably with ethanol to give a series of concentration ranging from $4-24 \mu \mathrm{g} / \mathrm{ml}$ of EFZ. The above solutions were scanned in the range of 200-400nm and the resultant spectra were derivatised to get the first order spectra as shown in Fig.2. The amplitude of the corresponding concentrations were measured in mm. The calibration curve was constructed by plotting amplitude versus concentration. The amount of EFZ was computed from the calibration curve.

\section{Sample Analysis:}

Pharmaceutical formulation of EFZ was successfully analysed by the proposed methods. Appropriate aliquots were subjected to the above methods and the amount of EFZ was determined from the calibration curves.

\section{RESULTS AND DISCUSSION:}

The optical characteristics such as absorption maxima, Beer's law limits, molar absorptivity and Sandell's sensitivity are furnished in Table-1. The regression characteristics like slope $(\mathrm{m})$, intercept(c), correlation coefficient(r), percent relative standard deviation(\% RSD) and standard error(SE) were calculated and the results are summarized in Table-1. The results of sample analysis 
showed that the drug determined by the proposed methods was in good agreement with the label claim proving the accuracy of the proposed methods. The results of sample analysis are furnished in Table-2.

To study the accuracy and reproducibility of the proposed methods, recovery experiments were carried out by adding a known amount of drug to preanalysed sample and the percentage recovery was calculated.

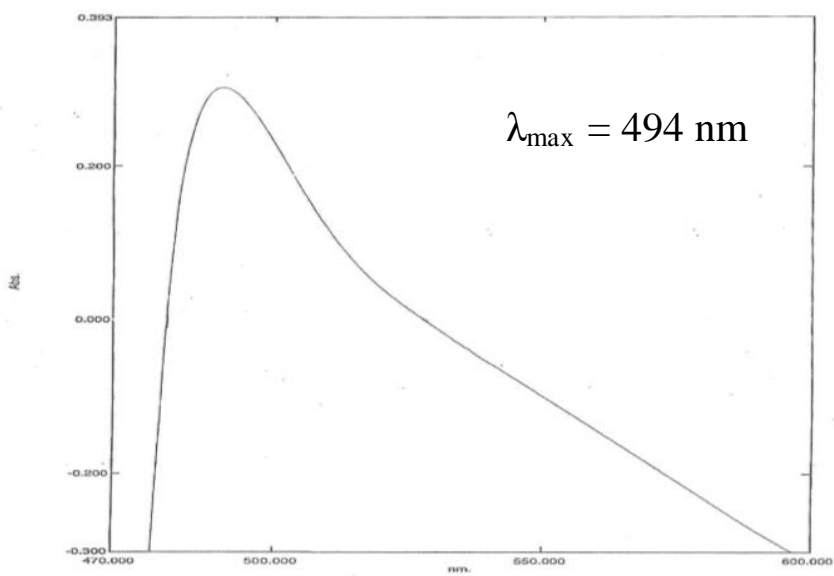

Figure 1: $\lambda_{\max }$ of pink chromogen of EFZ by Method A

The results are furnished in Table-2. The results indicate that there is no interference of other ingredients present in the formulations. Thus, the proposed methods are simple, sensitive, economical, accurate and reproducible and useful for the routine determination of EFZ in bulk drug and its pharmaceutical dosage forms.

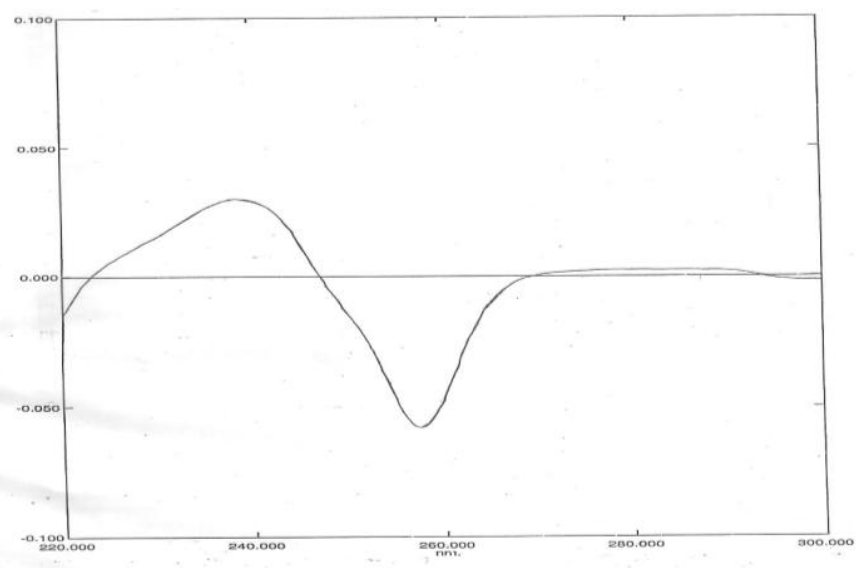

Figure 2: First derivative spectrum of EFZ by Method B

Table 1: Optical and Statistical parameters by Methods A and B

\begin{tabular}{|l|l|l|}
\hline Parameters & Method A & Method B \\
\hline $\begin{array}{l}\text { Absorption maximum/ } \\
\text { Wavelength range(nm) }\end{array}$ & 494 & $200-400$ \\
\hline Linearity Range $(\mu \mathrm{g} / \mathrm{ml})$ & $10-60$ & $4-24$ \\
\hline Correlation coefficient(r) & 0.999 & 0.998 \\
\hline$\%$ RSD & 0.0001 & 0.0005 \\
\hline Standard Error(SE) & 0.0424 & 0.0122 \\
\hline Regression Equation $\mathrm{y}=\mathrm{mx}+\mathrm{c}$ & $0.179 \mathrm{x}+0.0113$ & $0.0066 \mathrm{x}+0.1102$ \\
\hline Intercept $(\mathrm{c})$ & 0.0113 & 0.1102 \\
\hline Slope $(\mathrm{m})$ & 0.179 & 0.0066 \\
\hline Sandell's Sensitivity $\left(\mu \mathrm{gg} / \mathrm{cm}^{2} / 0.001 \mathrm{~A}\right.$ unit $)$ & 0.0008 & - \\
\hline Molar absorptivity $\left(\mathrm{Lmol} \mathrm{cm}^{-1}\right)$ & $3.6 \times 10^{3}$ & \\
\hline
\end{tabular}

Table 2: Assay and recovery of EFZ in dosage form

\begin{tabular}{|c|c|c|c|}
\hline Method & Labelled amount(mg) & Amount obtained(mg)* & Percentage recovery** \\
\hline A & 600 & 600.01 & $100.1 \%$ \\
\hline B & 600 & 600.02 & $99.99 \%$ \\
\hline
\end{tabular}

ACKNOWLEDGEMENTS: I am thankful to the Department of Pharmaceutical Chemistry, College of Pharmacy, Madras Medical College, Chennai-03, for providing the instrumentation and laboratory facilities.

\section{REFERENCES:}

1. Martindale, The complete drug reference, Pharmaceutical Press, London, $35^{\text {th }}$ Edition Vol-1, 200.P. 785 .

2. Seloi Mogatle, Isadore Kanfer, Rapid method for the quantitative determination of Efavirenz in human plasma, J Pharm Bio Med Anal, Vol.5, 2009,130.

3. Hamrapurkar P, Phale M, Shah N, Quantitative estimation of efavirenz by high performance thin layer chromatography, J Young Pharmacists, Vol.4, 2009, 359 .

4. Gita R, Simple and rapid liquid chromatography method for determination of Efavirenz in plasma, $J$ Chromatogr, Vol.1,2008, 5561.

5. Agnes I , Separation of efavirenz in human plasma by using reversed HPLC technique $J$ Chromatogr Vol-1, 2008 ,55-61.

6. Naser L Rezk, Richard R Tidwell, Angela DM Kashuba, Simple and rapid quantification of the non-nucleoside reverse transcriptase inhibitors Nevirapine, Delavirdine, Efavirenz in human blood plasma using high-performance liquid chromatography with ultraviolet absorbance detection, J Chromatogr, Vol.1,2002,79-88.

7. Matthews CZ, Woolf EJ, Mazenko RS , Haddix H Wiener, ChavezEng CM , Constanzer ML, Determination of Efavirenz, a selective non- nucleoside reverse transcriptase inhibitor, in human plasma using HPLC with post column photochemical derivatization and fluorescence detection,J of Pharm Biochem Anal, Vol.5, 2002, 925934.

8. Montgomery ER, Development and validation of reverse phase HPLC Method for analysis of efavirenz and its related substance in drug substance and capsule formulation, J Pharm Bio Med Analysis, 2001 $267-28$

9. Willard, Instrumental methods of analysis, $6^{\text {th }}$ Edition, CBS Publishers.P. 82-83.

10. Beckett A.H, Stenlake J.B,Practical Pharmaceutical Chemistry, Vol.II, $4^{\text {th }}$ edition, CBS Publishers, 1997. P. 301. 